\title{
First sexual intercourse and subsequent regret in three developing countries
}

\author{
Alfonso Osorio, $\mathrm{PhD}^{1,2}$ \\ Cristina López-del Burgo, $\mathrm{MD}, \mathrm{PhD}^{1,3}$ \\ Silvia Carlos, $\mathrm{PhD}^{1,3}$ \\ Miguel Ruiz-Canela, MPH, $\mathrm{PhD}^{1,4}$ \\ Miguel Delgado, MD, MPH, $\mathrm{PhD}^{5}$ \\ Jokin de Irala, $\mathrm{MD}, \mathrm{MPH}, \mathrm{PhD}^{1,3, *}$
}

${ }^{1}$ Institute for Culture and Society, University of Navarra (Pamplona, Spain)

${ }^{2}$ Department of Education, University of Navarra (Pamplona, Spain)

${ }^{3}$ Preventive Medicine and Public Health, University of Navarra (Pamplona, Spain)

${ }^{4}$ Department of Biomedical Humanities, University of Navarra (Pamplona, Spain)

${ }^{5}$ Area of Preventive Medicine, Department of Health Sciences, University of Jaen (Jaen, Spain)

* Corresponding author: Jokin de Irala, Preventive Medicine and Public Health, School of Medicine, University of Navarra, 31080 Pamplona, Spain. E-mail address: jdeirala@unav.es

\section{Published in: \\ Journal of Adolescent Health \\ (http://www.jahonline.org/)}

\section{See original article in the Journal's web page:}

http://www.sciencedirect.com/science/article/pii/S1054139X11002503

\section{Cite as:}

Osorio A, López-del Burgo C, Carlos S, Ruiz-Canela M, Delgado M. \& de Irala J (2012). First sexual intercourse and subsequent regret in three developing countries. Journal of Adolescent Health, 50, 271-278. 


\section{ABSTRACT}

Purpose: Adolescents who engage in sex can be affected by a range of negative physical and psychological consequences. We intend to analyze the reasons behind first sex, regret, and the association between reasons and regret.

Methods: A questionnaire was implemented to 8495 high schools students, aged 14-18, in the Philippines, El Salvador and Peru. Sexually active participants responded whether several circumstances were reasons involved in their first sexual relationship. They also responded whether they regretted having already had sexual relationships.

Results: More than a third of respondents reported at least one external pressure leading to first sex, and about half reported at least one reason implying getting carried away by sexual arousal.

More females affirmed they regret having already had sex. Logistic regression shows that reasons for first sex associated with regret were partner insistence, "uncontrolled situations" and seeing sexual images. These reasons were associated with regret even when love was also reported as related to first sex.

Conclusions: Adolescent sexual experience is often motivated by pressure and circumstances that lower the control over their decisions concerning sex, such as external pressure (because most friends already had sex or because of partner insistence) or getting carried away by sexual arousal (through an "uncontrolled situation" or viewing sexual images) rather than by mature decisions, and this may result in later regret. Adolescents should be helped by parents, educators and policy makers to be aware of these characteristics of adolescent sex and empowered to make assertive and informed decisions concerning their sexuality.

Key Words: Adolescent; Sexuality; Sexual Behavior; Sex Education; Love; Sexually transmitted infections; Sexual initiation; Regret 


\section{INTRODUCTION}

Adolescent sex is a matter of concern shared by parents, educators and health policy makers. Unhealthy behaviors such as having unprotected sex or having multiple partners are prevalent at younger ages, and ensuing physical consequences, such as sexually transmitted infections (STIs) and unplanned pregnancies, are problems still far from being solved. ${ }^{1-4}$

There is a higher incidence of depression and suicide attempts among sexually active teenagers, even after adjusting for age, sex, race, family structure and socio-economic status, as shown in the US, Finland and Estonia. ${ }^{5-7}$ Furthermore, several studies in the US and UK have shown that noteworthy percentages of sexually experienced youth wish they had waited longer to have sex for the first time, or some other negative feelings because of having had sex too soon, regardless of socio-demographic variables such as race and parental education. - $^{-}$ 11

The understanding of the motivations behind first sex in adolescents and the identification of variables associated with subsequent regret can enable future sexual education programs to prevent the unwanted physical and psychological consequences of sex. A study in New Zeland shows that males seem to have different reasons than females for having their first sexual relationship. ${ }^{12}$ There also seem to be different perceptions as to who was the more willing participant at first intercourse: males report their partner was the more willing participant more often than females report they were more willing. ${ }^{12,13}$

Sexual initiation is often influenced by external pressure. For example, different studies in developed countries affirm that youth, mostly females, consent to engage in unwanted sex. ${ }^{14-}$ ${ }^{16}$ Rates of sexual debut are higher in Rwanda when youth perceive that their peers are having sex. ${ }^{17}$ Other studies in the UK, Ireland and the US show associations between lack of control (feeling pressure, being drunk or stoned, and not planning sex) and regret. ${ }^{10,18,19}$ 
Most of the cited studies are from developed countries but a greater understanding of these issues is especially important in developing countries, where the empowerment of women is an urgent task. ${ }^{20}$

This study aims to describe the circumstances, reported by students in three developing countries, that motivated their first sexual encounter; and to determine which are associated with later regret. Based on the cited studies, our hypothesis is that reasons for first sex which imply lack of control will be associated with regret.

\section{METHODS}

This research is part of an ongoing international study (Project YOURLIFE), on what youth think and feel about relationships, love and sexuality. The methods of this project have been described elsewhere. ${ }^{21}$ The following is a brief description.

\section{The sample}

Project YOURLIFE is a cross sectional survey implemented in different countries through a multi-stage sampling of clusters representative of public and private schools within participating countries.

In the Philippines, we targeted approximately 4,000 students aged 13 to 24 from 28 public and private schools and universities within 7 representative political regions out of the 17 in the country. In El Salvador, we targeted approximately 3,000 students aged 13 to 18 from 30 public and private schools randomly selected within the three main urban areas of the country (San Salvador, Santa Ana and San Miguel). In Peru, we targeted approximately 3,000 students aged 13 to 18 from 62 public and private schools randomly selected among all the schools in the country. Schools selected came from all the 6 areas, and from 17 out of the 25 regions. 
These sample sizes took into account approximate sample size estimation criteria. ${ }^{22,23}$ We worked with the criteria that 10 subjects would be needed per parameter included in a statistical model used to adjust for confounding. With these samples we were confident to have sufficient statistical power to account for sufficient variables in a given model.

We recruited 3,597 respondents from the Philippines, 2,809 from El Salvador and 3,399 from Peru. For this analysis, we excluded subjects older than 18 because these ages were only present in the Filipino sample, and those aged 13, because they were very few in all samples. Subjects aged 14-18 were 3,016, 2,195 and 3,284, respectively, with a total of 8,495 adolescents from the three countries for this analysis.

\section{Data Collection}

The questionnaire was implemented in 2007 in the Philippines, in 2008 in El Salvador, and in 2009 in Peru. Data were collected using standardized data-collection protocols. ${ }^{21}$ Prior to administering the survey to students, consent was obtained through the schools.

Data collectors travelled to each school to administer the survey during class hours. Questionnaire administration in schools (that is, away from parents), and by persons other than the teachers, has the reported benefit of increasing the respondents' sense of privacy and their willingness to disclose sensitive information. ${ }^{24}$

Survey procedures were designed to protect student privacy by ensuring anonymous participation. Ethical approval was obtained from the Ethics Committee of the University of Asia and the Pacific (The Philippines) for the English version, and from the Ethics Committee of the University of Malaga (Spain) for the Spanish version. 


\section{The questionnaire}

Paper-pencil questionnaires were developed to gather information on several aspects of adolescent's lifestyles. The questionnaires, written in colloquial English (for the Philippines) or Spanish (for El Salvador and Peru), had primarily close-ended questions. They were pilot tested and adjusted to ensure clarity, comprehension and suitability to local conditions, and to require about 45 minutes for completion. Attitudinal questions were presented on a five-point Likert scale.

\section{Reasons for first sexual relationship}

In this analysis of Project YOURLIFE, adolescents who had already had sexual relationships were selected. The questionnaire defines “sexual relationships” as «complete sexual relationships, also known as "making love”, "having sex”». The wording in the Spanish version was: «relaciones sexuales completas, también llamadas "hacer el amor”, "hacerlo todo", "llegar hasta el final”»

Adolescents who had ever had sex were asked to respond whether or not they agreed that different reasons influenced their decision for their first sexual relationship. The wording was: “I had my first sexual relationship because ...”. And several possible reasons followed (see Results section and Tables).

Furthermore, subjects were asked whether they had ever had sex "with my partner (“boyfriend/girlfriend”) without giving my consent” (the specification "with my partner” was not present in the previous questions about reasons for first sex).

For all these questions, in El Salvador and Peru, subjects had 3 answer options: "yes”, "no” and “don't know”. In the Philippines, however, the response format was a 5-point Likert scale (from “strongly disagree” to "strongly agree”), and a “don’t know” option. In the Philippines, 
when recoding these variables, we considered as "yes" the two highest answer options (“agree” and "strongly agree”).

\section{Definition of regret}

Participants were asked whether they agreed with the sentence "Deep down, I regret having already had sexual relationships”. Response options were the same as in the previous paragraph (yes/no in El Salvador and Peru; Likert scale in the Philippines).

\section{Other variables}

The questionnaire also included socio-demographic information, leisure activities, opinions, sources of information and communication with parents about love and sex.

\section{Analysis}

Descriptive analysis

We performed weighted analyses in order for the descriptive results to be representative of each country's student population with regard to the distribution of males and females, and of type of centers. In each country, we obtained population-wide distributions of females and males, and of public and private centers. For the subjects in each cell of the resulting 2x2 table, the weight was $\mathrm{P} / \mathrm{S}$, where $\mathrm{P}$ is the proportion the cell represents in the population, and S is the proportion the cell represents in the sample. For example, if $40.5 \%$ of $14-18$ Salvadorean adolescents are females in public schools, and in our sample these subjects are $34.5 \%$ of the Salvadorean subsample, then the weight value for this group was $40.5 / 34.5=1.17$. 
Regarding data on sexual initiation, we have specified the age-specific percentage of sexually initiated adolescents instead of mean age of first sex because averages may lead to biased interpretations of the extent of sexual initiation. ${ }^{25}$

Two composite variables were created to quantify how many adolescents had their first sexual relation because of specific reasons of interest to the study:

- External pressure. Respondents were coded as 1 (“yes”) if they reported at least one of the following reasons for having first sex: "Most of my friends already had sex", "I wanted to be more popular”, "I was afraid to lose him/her”, "I did not know how to say no to a person who insisted”. Those not reporting any of the above, or having missing values, were coded as 0 (“no”).

- Getting carried away by sexual arousal. Respondents were coded as 1 (“yes”) if they reported at least one of the following reasons for having first sex: “As a result of an uncontrolled situation, although it was not initially our (mine and my partner's) intention”, “As a consequence of seeing sexual images (films, magazines...)”. Those who did not report any of the above, or had missing values, were coded as 0 ("no").

Fisher's exact test was used to assess the difference between proportions among males and females on dichotomous variables.

Differences across countries were assessed using ANOVAs and Bonferroni contrasts.

\section{Multivariate analysis}

Multivariate non-conditional logistic regression models were fit with regret as outcome. We introduced, as possible independent variables, the main socio-demographic variables (country, age, sex, religiosity), reasons for first sex, and sex without consent. For regret and for variables concerning reasons for first sex and sex without consent, subjects answering "yes” 
were compared to all other subjects (including those answering “no” and “don’t know”, and those not answering the question).

All $p$ values presented are 2-tailed; $p<0.05$ was considered statistically significant. All analyses were performed using the SPSS 15.0 statistical package (Chicago, IL, USA; IBM).

\section{RESULTS}

The majority of the respondents were female (55.2\%) and from public schools (53.6\%). After weighting by these two variables, mean age was 15.7 ( $\mathrm{SD}=1.3)$, most adolescents were Catholic (66.8\%) and came from middle-income families (72.9\%) (Table 1).

Regarding sexual experience (Table 2), 31.5\% of males and $14.0 \%$ of females indicated they were sexually initiated. El Salvador had the highest percentages and Peru the lowest. In the three countries, initiation was higher among adolescents with no religion; the relationship between sexual initiation and economic status varies across countries, and there were virtually no differences between public and private schools.

\section{Reasons for first sex}

In the three countries, the reason most frequently reported by females for having had first sex was "I was in love”. For males, the most frequent reason was "I felt like it" in El Salvador and Peru, and "I wanted to know what it was like” in the Philippines (Table 3).

Females reported love as a reason more frequently than males in El Salvador. However, in the three countries, males reported the following reasons more frequently: “I wanted to have fun”, “I wanted to know what it was like.”, "I felt like it”, "Most of my friends already had sex”, “I wanted to be more popular”, and “As a consequence of seeing sexual images”.

After grouping these reasons, more than a third of respondents reported at least one external pressure, and about a half reported at least one reason implying getting carried away by sexual 
arousal. External pressure was more frequent among males in El Salvador and Peru; and getting carried away by sexual arousal was more frequent among males in the Philippines and Peru (Table 3).

\section{Regret}

Among respondents who had had sexual relationships, around a fifth agreed with the statement: "Deep down, I regret having already had sexual relationships". Regret was significantly more frequent among females in El Salvador and Peru. (Table 3).

Using the multivariate logistic regression, and adjusting for sex, age and other relevant variables (Table 4), the following reasons for first sex were independently associated with regret: first sex due to partner's insistence (OR=1.90; 95\% CI: 1.38 to 2.63), first sex resulting from an uncontrolled situation $(\mathrm{OR}=1.68 ; 95 \% \mathrm{CI}$ : 1.26 to 2.23$)$, and first sex as a consequence of seeing sexual images (OR=2.07; 95\% CI: 1.46 to 2.92).

Interactions were tested in the model between the variable "I had my first sexual relationship because I was in love” and each of the three reasons that were associated with regret. None were significantly associated with regret.

\section{DISCUSSION}

A relevant finding in our study is the high proportion of adolescents in the three countries reporting reasons that imply impaired control (because of external pressure and/or because of getting carried away by sexual arousal). Some official messages are tailored to help adolescents avoid such pressures: for example, by reminding them that they can be more proactive choosing not to have sex if this is their choice and that many their age are making this choice. ${ }^{26}$ 
Some studies describe sexual initiation as a sign of maturity, a transition rite to adulthood, a decision made by those ready for the step. ${ }^{27,28}$ This perspective may not be taking into account that adolescent sexual initiation is not usually the result of a deliberate and mature enough decision. Rather, it is frequently the consequence of a conjunction of factors that often include impaired control or pressure. In this study most sexually experienced males and females had their first sexual relationship with a certain degree of control impairment.

There are differences between males and females in the reasons reported for having first sex. In one country, females chose "love" as a reason more frequently than males. However, in the three countries, males chose other reasons such as social pressure, getting carried away by sexual arousal, looking for fun, or curiosity more frequently.

These results show that males and females did not have the same motivations when engaging in their first sexual relationship. These differences can explain the sex-specific affective reactions to first coitus found in other studies and which are generally less positive for females. For example, research shows that females report less physiological and psychological satisfaction and more sadness, guilt, nervousness, tension, embarrassment and fear in Eastern Europe, Turkey and the US, adjusting for religiosity, planning of the sexual encounter, making the first step or contraceptive use. ${ }^{29-31}$

We have also found that approximately one fifth of students indicated experiencing regret for having already had sex. Some studies show higher percentages, especially among females, $8,11-$ 13,32-35 which may reflect differences in the wording we used to pick up this information. We used "I regret having already had sexual relationships", whereas the references cited above have used "I wish I had waited longer”. Referring directly to "regret” could be perceived as a stronger statement than "I wish I had waited longer", thus accounting for our lower percentages of regret. As well, comparisons between studies conducted in different countries, are not easily interpretable. 
In addition, our questionnaire refers to regretting "having already had sexual relationships”, while other studies refer only to regret over the "first sexual relationship". Regret over "first sex” will more likely be higher than regret over "having already had sex".

These percentages are high enough to believe there is room for developing more life skills and training to balance the idealistic and supposedly "risk free” images of adolescent sexual initiation often conveyed to youth. For example, Carpenter showed how a German teen magazine depicts an exclusively positive image of virginity loss, ${ }^{36}$ and in the United States Rivadeneyra and Lebo found that "the messages represented in television may give adolescents the idea that sexual activity is common, casual, and trouble-free, with specific gender roles to fulfill —all of which are potential factors in sexual risk". ${ }^{37}$ We did not come accross similar studies in developing countries.

We confirm that having had sexual relationships without consent seems to increase later regret. Furthermore, subjects who reported partner insistence or getting carried away by sexual arousal as reasons for their first sex were also more likely to report regret. These results suggest that situations such as viewing sexual images might be leading adolescents to sexual encounters that are not necessarily "planned", thus resulting in regret. Sex education seeking the empowerment of adolescents should include discussions about this association between uncontrolled sexual drive and sexual encounters that more frequently end up being regretted. Contrary to these findings, some sex education programs invite adolescents to practice “petting” or "outercourse” as a safe alternative to coital experiences. ${ }^{38,39}$ These recommendations may in fact increase the risk of an unwanted coital relationship that was intended to be prevented in the very first place. Something similar can be said concerning the low control over pornographic material often available to underage youth.

It is interesting to note that having had the first sexual relationship because of being in love does not decrease the risk of regret. Furthermore, since no significant interactions were found, 
it seems that, even when love is reported as one of the reasons for first sex, the concurrent presence of other reasons such as partner insistence, an uncontrolled situation or viewing sexual images may still lead to regret.

It is not surprising to find that religious adolescents feel more regret over sexual experience, since the religions that are prevalent in these countries promote abstinence from sex before marriage.

According to social norms theory, people's actions are influenced by their perception of peer behavior and whether an action is socially accepted by the social group one belongs to. ${ }^{40}$ In our results, El Salvador is the country with the highest prevalence of non religiosity, and with lowest percentage of Catholics. Therefore, it is not surprising to find that this country has the highest prevalence of sexual initiation, with the lowest prevalence of regret. However, it is interesting to note that the other associations were still present even after adjusting for religiosity.

A clear limitation of our study is its cross-sectional design. It is usually more difficult to assume causality between variables. However, some associations can be more safely assumed as causal. The adjusted associations between reported circumstances surrounding the first sexual relationship (such as impaired control), and later regret, is quite plausible, as reverse causation between these events seems reasonably unlikely.

Other causal explanations might likewise be possible, like the presence of other factors influencing both the first sexual relationship and subsequent regret. By adjusting our model for several possible confounders, we have tried to minimize this problem.

The wording we used to measure regret could be improved. However, any bias resulting from our wording is most likely towards the null. The extent of regret, estimated in our study should in any case be considered an underestimation and therefore warrants attention. 
On the basis of questionnaires, social desirability bias is a possible menace to validity in all studies. In the descriptive results, social desirability may have lowered the reporting of regret and of some reasons involved in first sex, such as "I was afraid to lose him/her" or "I was under the influence of alcohol or drugs”. On the other hand, this same bias may have raised the reporting of first sex because of being in love. In order to reduce these types of bias, emphasis was placed on privacy and anonymity of data.

The sample in El Salvador was chosen only in urban areas, and therefore it cannot be assumed that results apply to the whole country. However, the fact that the results are consistent across countries is reassuring.

Generalization of our results to other developing countries cannot be assumed without caution. Though we have studied three developing countries in different world regions, not all regions have been covered. Furthermore, our three countries are mostly Christian (mainly Catholic). Further studies might have to replicate our results in other cultures. In any case, our multivariate analyses have always adjusted for religiosity to take this characteristic into account.

Important strengths of the study are its representativeness, the large sample size and the presence of data from three developing countries located in different world regions (SouthEast Asia, Central America and South America). We were able to improve the internal validity of our results by working on, and adjusting for, an important number of plausible confounders. This was possible thanks to our large sample size.

To our knowledge, this is the first study that has implemented the same questionnaire about relationships, love and sexuality on representative student populations from three developing countries; furthermore, it addresses the prevalence of first sexual relationships driven by lack of control over external pressure or as a result of getting carried away by sexual arousal, as well as the subsequent regret. 
In conclusion, despite love being quite commonly reported as a factor in adolescents' decision to engage in sex for the first time, some external pressure and/or getting carried away by sexual arousal were simultaneously present as reasons for sexual debut in the majority of participants. Some of these reasons were significantly associated with regret in spite of the reporting of love as a motivation for first sex. These issues should be discussed in sex education programs and taken into account in public advertisements directed to adolescents in order to empower them to make better informed decisions concerning their sexuality by avoiding situations of pressure and lack of control on sexual drive.

\section{ACKNOWLEDGEMENTS}

This work was partially financially supported by Intermedia Consulting (Italy), the University of Asia and the Pacific (the Philippines), Concultura (El Salvador), the University of Piura (Peru) and the University of Navarra (Spain).

We thank Paul Birch and Matthew Evans for their insights on initial versions of this manuscript, and Matthew Hanley for reviewing the English language. 
Table 1. Socio-demographic characteristics of the sample

\begin{tabular}{|c|c|c|c|c|}
\hline $\begin{array}{l}\text { Sociodemographic } \\
\text { characteristics }\end{array}$ & $\begin{array}{c}\text { Philippines } \\
(\mathbf{N}=3016)^{*} \\
\text { n (\%) }\end{array}$ & $\begin{array}{c}\text { El Salvador } \\
(\mathrm{N}=2195)^{*} \\
\mathrm{n}(\%) \\
\end{array}$ & $\begin{array}{c}\text { Peru } \\
(\mathrm{N}=3284) * \\
\text { n }(\%)\end{array}$ & $\begin{array}{c}\text { Total } \\
(\mathrm{N}=\mathbf{8 4 9 5})^{*} \\
\mathbf{n}(\%) \\
\end{array}$ \\
\hline \multicolumn{5}{|l|}{ Sex } \\
\hline Male & $1369(45.4)$ & 1103(50.3) & $1707(52.0)$ & $4179(49.2)$ \\
\hline Female & $1647(54.6)$ & $1092(49.7)$ & $1577(48.0)$ & $4316(50.8)$ \\
\hline \multicolumn{5}{|l|}{ School } \\
\hline Public & $2404(79.7)$ & 1786(81.4) & $2721(82.9)$ & $6911(81.4)$ \\
\hline Private & $612(20.3)$ & $409(18.6)$ & $563(17.1)$ & $1584(18.6)$ \\
\hline \multicolumn{5}{|l|}{ Age } \\
\hline 14 & $414(13.7)$ & $549(25.0)$ & $805(24.5)$ & $1768(20.8)$ \\
\hline 15 & $741(24.6)$ & $500(22.8)$ & $943(28.7)$ & $2184(25.7)$ \\
\hline 16 & $758(25.1)$ & 433(19.7) & $1007(30.7)$ & $2198(25.9)$ \\
\hline 17 & $576(19.1)$ & $422(19.2)$ & $425(12.9)$ & $1423(16.8)$ \\
\hline 18 & $527(17.5)$ & 291(13.3) & $104(3.2)$ & $922(10.9)$ \\
\hline \multicolumn{5}{|l|}{ Religion } \\
\hline No religion & 57 (1.9) & $338(16.4)$ & $425(13.2)$ & $820(9.9)$ \\
\hline Catholic & $2490(82.6)$ & $914(44.4)$ & $2137(66.2)$ & $5541(66.8)$ \\
\hline Evangelic/Protestant & $319(10.6)$ & $709(34.5)$ & $453(14.0)$ & $1481(17.8)$ \\
\hline Other $^{\dagger}$ & $149(4.9)$ & $96(4.7)$ & $214(6.6)$ & $459 \quad(5.5)$ \\
\hline \multicolumn{5}{|l|}{ Economic status $^{\ddagger}$} \\
\hline Very low, low & $466(15.5)$ & $423(20.5)$ & $551(17.1)$ & $1440(17.4)$ \\
\hline Middle & $2366(78.4)$ & $1390(67.4)$ & $2291(71.2)$ & $6047(72.9)$ \\
\hline High, very high & $184(6.1)$ & $248(12.0)$ & $377(11.7)$ & 809 (9.8) \\
\hline
\end{tabular}

* Totals vary because some items were not responded by some participants.

$\dagger$ Other religions include Jehovah's Witnesses, Mormons, Jews, Muslims and other religions which vary across the different countries.

‡ Based on the respondents' perception of family economic status. 
Table 2. Number (and percentage) of sexually initiated adolescents in each country, by key demographic variables

\begin{tabular}{|c|c|c|c|c|}
\hline $\begin{array}{l}\text { Sociodemographic } \\
\text { characteristics }\end{array}$ & $\begin{array}{l}\text { The Philippines } \\
\text { (N=3016)* } \\
\text { n (\%) }\end{array}$ & $\begin{array}{c}\text { El Salvador } \\
(\mathrm{N}=2195)^{*} \\
\mathrm{n}(\%)\end{array}$ & $\begin{array}{c}\text { Peru } \\
(\mathrm{N}=3284)^{*} \\
\mathbf{n}(\%)\end{array}$ & $\begin{array}{c}\text { Total } \\
(\mathrm{N}=\mathbf{8 4 9 5})^{*} \\
\mathbf{n}(\%)\end{array}$ \\
\hline \multicolumn{5}{|l|}{ By sex } \\
\hline Males & $453(33,1)$ & $340(33,7)$ & $485(28,9)$ & $1278(31,5)$ \\
\hline Females & $234(14,2)$ & $179(17,4)$ & $180(11,5)$ & $593(14,0)$ \\
\hline \multicolumn{5}{|l|}{ By school } \\
\hline Public & $552(23.0)$ & $422(25.7)$ & $571(21.3)$ & $1545(22.9)$ \\
\hline Private & $136(22.2)$ & $97(24.7)$ & $94(16.9)$ & $327(21.0)$ \\
\hline \multicolumn{5}{|l|}{ By age } \\
\hline 14 & $67(16,2)$ & $75(15,7)$ & $90(11,3)$ & $232(13,7)$ \\
\hline 15 & $102(13,8)$ & $98(21,0)$ & $172(18,5)$ & $372(17,4)$ \\
\hline 16 & $176(23,2)$ & $110(26,8)$ & $235(23,5)$ & $521(24,0)$ \\
\hline 17 & $167(29,0)$ & $127(31,9)$ & $126(30,4)$ & $420(30,3)$ \\
\hline 18 & $176(33,4)$ & $109(38,8)$ & $42(41,6)$ & $327(36,0)$ \\
\hline \multicolumn{5}{|l|}{ By religion } \\
\hline No religion & $27(47.4)$ & $108(35.0)$ & $105(24.9)$ & $240(30.5)$ \\
\hline Catholic & $568(22.8)$ & $196(22.3)$ & $409(19.3)$ & $1173(21.4)$ \\
\hline Evangelic/Protestant & $55(17.2)$ & $158(23.6)$ & $98(22.0)$ & $311(21.7)$ \\
\hline Other $^{\dagger}$ & $37(24.8)$ & $28(31.8)$ & $35(16.7)$ & $100(22.4)$ \\
\hline \multicolumn{5}{|l|}{ By economic status ${ }^{\ddagger}$} \\
\hline Very low, low & $120(25.8)$ & $108(26.8)$ & $123(22.7)$ & $351(24.9)$ \\
\hline Middle & $539(22.8)$ & $328(24.7)$ & $432(19.0)$ & $1299(21.8)$ \\
\hline High, very high & $29(15.8)$ & $69(29.9)$ & $98(26.4)$ & $196(24.9)$ \\
\hline $\begin{array}{ll}* & \text { Totals vary becaus } \\
\dagger & \text { Other religions inc } \\
& \text { which vary across } \\
\ddagger & \text { Based on the resno }\end{array}$ & $\begin{array}{l}\text { e items were not re } \\
\text { Jehovah's Witnesse } \\
\text { fferent countries. }\end{array}$ & $\begin{array}{l}\text { ponded by som } \\
\text { Mormons, Jew }\end{array}$ & $\begin{array}{l}\text { rticipants. } \\
\text { Iuslims and }\end{array}$ & igions \\
\hline
\end{tabular}


Table 3. Reasons for first sexual relationship among adolescents reporting having had sex, and regret

\begin{tabular}{|c|c|c|c|c|c|c|c|c|}
\hline & \multicolumn{2}{|c|}{ Philippines } & \multicolumn{2}{|c|}{ El Salvador } & \multicolumn{2}{|c|}{ Peru } & \multicolumn{2}{|c|}{$\begin{array}{l}\text { Inter-country } \\
\text { differences }\end{array}$} \\
\hline & $\begin{array}{c}\text { Males } \\
(\mathrm{N}=453) \\
\%\end{array}$ & $\begin{array}{c}\text { Females } \\
(\mathrm{N}=234) \\
\%\end{array}$ & $\begin{array}{c}\text { Males } \\
(\mathrm{N}=340) \\
\%\end{array}$ & $\begin{array}{c}\text { Females } \\
(\mathrm{N}=179) \\
\%\end{array}$ & $\begin{array}{c}\text { Males } \\
(\mathrm{N}=485) \\
\%\end{array}$ & $\begin{array}{c}\text { Females } \\
(\mathrm{N}=180) \\
\%\end{array}$ & Males & Females \\
\hline $\begin{array}{l}\text { Reasons for first sexual } \\
\text { relationship } \\
\text { I was in love }\end{array}$ & 44.4 & 45.7 & 40.0 & $56.4^{\ddagger}$ & 50.5 & 50.6 & $\mathrm{Sa}<\mathrm{Pe}$ & - \\
\hline I wanted to have fun & 38.2 & $12.4^{\ddagger}$ & 36.5 & $12.3^{\ddagger}$ & 48.0 & $15.0^{\ddagger}$ & $\begin{array}{l}\mathrm{Ph}<\mathrm{Pe} \\
\mathrm{Sa}<\mathrm{Pe}\end{array}$ & - \\
\hline $\begin{array}{l}\text { I wanted to know what } \\
\text { it was like }\end{array}$ & 47.6 & $26.5^{\ddagger}$ & 44.7 & $27.4^{\ddagger}$ & 55.3 & $38.3^{\ddagger}$ & $\mathrm{Sa}<\mathrm{Pe}$ & $\mathrm{Ph}<\mathrm{Pe}$ \\
\hline I felt like it & 39.0 & $18.4^{\ddagger}$ & 60.6 & $40.8^{\ddagger}$ & 72.4 & $45.6^{\ddagger}$ & $\mathrm{Ph}<\mathrm{Sa}<\mathrm{Pe}$ & $\begin{array}{l}\mathrm{Ph}<\mathrm{Sa} \\
\mathrm{Ph}<\mathrm{Pe}\end{array}$ \\
\hline $\begin{array}{l}\text { Most of my friends } \\
\text { already had sex }\end{array}$ & 15.9 & $9.8 *$ & 11.5 & $2.8^{\ddagger}$ & 29.1 & $5.6^{\ddagger}$ & $\begin{array}{l}\mathrm{Ph}<\mathrm{Pe} \\
\mathrm{Sa}<\mathrm{Pe}\end{array}$ & $\mathrm{Ph}>\mathrm{Sa}$ \\
\hline $\begin{array}{l}\text { I wanted to be more } \\
\text { popular }\end{array}$ & 13.4 & $6.0^{\dagger}$ & 9.4 & $2.8^{\dagger}$ & 17.3 & $1.7^{\ddagger}$ & $\mathrm{Sa}<\mathrm{Pe}$ & - \\
\hline $\begin{array}{l}\text { I was afraid to lose } \\
\text { him/her }\end{array}$ & 22.9 & 27.4 & 11.5 & 7.2 & 21.4 & $11.1^{\dagger}$ & $\begin{array}{l}\mathrm{Ph}>\mathrm{Sa} \\
\mathrm{Sa}<\mathrm{Pe}\end{array}$ & $\begin{array}{l}\mathrm{Ph}>\mathrm{Sa} \\
\mathrm{Ph}>\mathrm{Pe}\end{array}$ \\
\hline $\begin{array}{l}\text { I did not know how to } \\
\text { say no to a person who } \\
\text { insisted }\end{array}$ & 15.0 & 18.8 & 21.2 & $13.4 *$ & 18.1 & 15.0 & - & - \\
\hline $\begin{array}{l}\text { I was under the } \\
\text { influence of alcohol } \\
\text { or drugs }\end{array}$ & 4.9 & $9.0 *$ & 5.9 & 5.0 & 12.8 & $5.0^{\dagger}$ & $\begin{array}{l}\mathrm{Ph}<\mathrm{Pe} \\
\mathrm{Sa}<\mathrm{Pe}\end{array}$ & - \\
\hline $\begin{array}{l}\text { As a result of an } \\
\text { "uncontrolled } \\
\text { situation" }\end{array}$ & 23.8 & 24.3 & 52.1 & 47.5 & 59.8 & 51.7 & $\begin{array}{l}\mathrm{Ph}<\mathrm{Sa} \\
\mathrm{Ph}<\mathrm{Pe}\end{array}$ & $\begin{array}{l}\mathrm{Ph}<\mathrm{Sa} \\
\mathrm{Ph}<\mathrm{Pe}\end{array}$ \\
\hline $\begin{array}{l}\text { As a consequence of } \\
\text { seeing sexual images }\end{array}$ & 26.7 & $12.4^{\ddagger}$ & 14.1 & $2.8^{\ddagger}$ & 23.3 & $5.0^{\ddagger}$ & $\begin{array}{l}\mathrm{Ph}>\mathrm{Sa} \\
\mathrm{Sa}<\mathrm{Pe}\end{array}$ & $\begin{array}{l}\mathrm{Ph}>\mathrm{Sa} \\
\mathrm{Ph}>\mathrm{Pe}\end{array}$ \\
\hline External pressure ${ }^{\S}$ & 42.6 & 41.3 & 32.1 & $20.1^{\dagger}$ & 46.4 & $26.1^{\ddagger}$ & $\begin{array}{l}\mathrm{Ph}>\mathrm{Sa} \\
\mathrm{Sa}<\mathrm{Pe}\end{array}$ & $\begin{array}{l}\mathrm{Ph}>\mathrm{Sa} \\
\mathrm{Ph}>\mathrm{Pe}\end{array}$ \\
\hline $\begin{array}{l}\text { Getting carried away } \\
\text { by sexual arousal }\end{array}$ & 39.0 & $28.6^{\dagger}$ & 56.5 & 47.5 & 63.5 & $54.2 *$ & $\begin{array}{l}\mathrm{Ph}<\mathrm{Sa} \\
\mathrm{Ph}<\mathrm{Pe}\end{array}$ & $\begin{array}{l}\mathrm{Ph}<\mathrm{Sa} \\
\mathrm{Ph}<\mathrm{Pe}\end{array}$ \\
\hline $\begin{array}{l}\text { Deep down, I regret having } \\
\text { already had sexual } \\
\text { relationships }\end{array}$ & 20.5 & 24.7 & 12.6 & $30.2^{\dagger}$ & 18.6 & $31.7^{\dagger}$ & $\mathrm{Ph}>\mathrm{Sa}$ & - \\
\hline
\end{tabular}

Percentages do not add up to $100 \%$ because respondents could select more than one reason. Subjects with missing values are included in the denominators: these cases range, in the whole sample, from $8.4 \%$ to $11.8 \%$.

Differences between sexes within each country ( $p$ value of two-tailed Fisher's Exact test):

$$
{ }^{*} \mathrm{p}<0.05 ;^{\dagger} \mathrm{p}<0.01 ;^{\ddagger} \mathrm{p}<0.001
$$

Inter-country differences are reported, within each sex, when $\mathrm{p}<0.05$ (ANOVA with Bonferroni contrasts):

$\mathrm{Ph}=$ Philippines; $\mathrm{Sa}=$ El Salvador; $\mathrm{Pe}=$ Peru

$\S$ Respondents who reported at least one of the following reasons for first sex: "Most of my friends already had sex", "I wanted to be more popular", "I was afraid to lose him/her", "I did not know how to say no to a person who insisted".

Respondents who reported at least one of the following reasons for first sex: "As a result of an uncontrolled situation", "As a consequence of seeing sexual images". 
Table 4. Variables associated with regretting having already had sex among adolescents reporting having had sex

\begin{tabular}{|c|c|c|c|}
\hline Independent variables & $\begin{array}{r}\text { Regret }^{\dagger} \\
\text { n (\%) }\end{array}$ & Crude OR (95\% CI) & Adjusted OR (95\% CI) \\
\hline \multicolumn{4}{|c|}{ Reasons for first sexual relationship } \\
\hline \multicolumn{4}{|l|}{ Seeing sexual images } \\
\hline No $(\mathrm{N}=1548)$ & $282(18.2)$ & (ref) & (ref) \\
\hline Yes $(\mathrm{N}=324)$ & $113(34.9)$ & $2.40(1.84-3.12)$ & $2.07(1.47-2.92) * * *$ \\
\hline \multicolumn{4}{|c|}{$\begin{array}{l}\text { Because of an "uncontrolled } \\
\text { situation" }\end{array}$} \\
\hline No $(\mathrm{N}=1064)$ & $171(16.1)$ & (ref) & (ref) \\
\hline Yes $(\mathrm{N}=808)$ & $223(27.6)$ & $1.99(1.59-2.50)$ & $1.68(1.26-2.24) * * *$ \\
\hline \multicolumn{4}{|c|}{ I did not know how to say no to a person who insisted } \\
\hline No $(\mathrm{N}=1549)$ & $282(18.2)$ & (ref) & (ref) \\
\hline Yes $(\mathrm{N}=323)$ & $112(34.7)$ & $2.39(1.83-3.10)$ & $1.90(1.38-2.62) * * *$ \\
\hline \multicolumn{4}{|l|}{ I was in love } \\
\hline No $(\mathrm{N}=990)$ & 197 (19.9) & (ref) & (ref) \\
\hline Yes $(\mathrm{N}=882)$ & $197(22.3)$ & $1.16(0.93-1.45)$ & $0.91(0.70-1.19)$ \\
\hline \multicolumn{4}{|l|}{ I wanted to have fun } \\
\hline No $(\mathrm{N}=1263)$ & $257(20.3)$ & (ref) & (ref) \\
\hline Yes $(N=608)$ & $137(22.5)$ & $1.14(0.90-1.44)$ & $0.73(0.52-1.01)$ \\
\hline \multicolumn{4}{|c|}{ I wanted to know what it was like. } \\
\hline No $(\mathrm{N}=1055)$ & $192(18.2)$ & (ref) & (ref) \\
\hline Yes $(N=816)$ & $202(24.8)$ & $1.48(1.18-1.85)$ & $1.14(0.86-1.52)$ \\
\hline \multicolumn{4}{|l|}{ I felt like it } \\
\hline No $(N=940)$ & $178(18.9)$ & (ref) & (ref) \\
\hline Yes $(\mathrm{N}=932)$ & $217(23.3)$ & $1.30(1.04-1.62)$ & $1.10(0.81-1.48)$ \\
\hline \multicolumn{4}{|c|}{ Most of my friends already had sex } \\
\hline No $(\mathrm{N}=1582)$ & $329(20.8)$ & (ref) & (ref) \\
\hline Yes $(N=289)$ & $65(22.5)$ & $1.11(0.82-1.50)$ & $0.77(0.51-1.15)$ \\
\hline \multicolumn{4}{|c|}{ I wanted to be more popular } \\
\hline No $(N=1673)$ & $345(20.6)$ & (ref) & (ref) \\
\hline Yes $(\mathrm{N}=199)$ & $49(24.6)$ & $1.27(0.90-1.78)$ & $0.83(0.51-1.33)$ \\
\hline \multicolumn{4}{|c|}{ I was afraid to lose him/her } \\
\hline No $(\mathrm{N}=1528)$ & $291(19.0)$ & (ref) & (ref) \\
\hline Yes $(\mathrm{N}=344)$ & $104(30.2)$ & $1.84(1.41-2.39)$ & $1.17(0.83-1.66)$ \\
\hline \multicolumn{4}{|c|}{ I was under the influence of alcohol or drugs } \\
\hline No $(\mathrm{N}=1727)$ & $348(20.2)$ & (ref) & (ref) \\
\hline Yes $(N=145)$ & $47(32.4)$ & $1.89(1.31-2.72)$ & $1.09(0.69-1.72)$ \\
\hline \multicolumn{4}{|l|}{ Socio-demographic variables } \\
\hline \multicolumn{4}{|l|}{ Country } \\
\hline El Salvador $(\mathrm{N}=520)$ & $97(18.7)$ & (ref) & (ref) \\
\hline Philippines $(\mathrm{N}=687)$ & $150(21.8)$ & $1.23(0.92-1.63)$ & $1.37(0.98-1.92)$ \\
\hline Peru $(\mathrm{N}=665)$ & $147(22.1)$ & $1.25(0.94-1.66)$ & $1.44(1.04-1.99) *$ \\
\hline \multicolumn{4}{|l|}{ Sex } \\
\hline Male $(\mathrm{N}=1279)$ & $226(17.7)$ & (ref) & (ref) \\
\hline Female $(N=594)$ & $169(28.5)$ & $1.85(1.47-2.33)$ & $2.18(1.66-2.87) * * *$ \\
\hline \multicolumn{4}{|l|}{ Religiosity $^{\S}$} \\
\hline Not high $(\mathrm{N}=1214)$ & $230(18.9)$ & (ref) & (ref) \\
\hline $\operatorname{High}(\mathrm{N}=658)$ & $165(25.1)$ & $1.43(1.14-1.80)$ & $1.49(1.15-1.95) * *$ \\
\hline \multicolumn{4}{|c|}{ Sex at least once with boyfriend/girlfriend without consent } \\
\hline No $(N=1505)$ & $259(17.2)$ & (ref) & (ref) \\
\hline Yes $(\mathrm{N}=367)$ & $135(36.8)$ & $2.80(2.18-3.60)$ & $2.24(1.68-3.00) * * *$ \\
\hline \\
\hline \multirow{2}{*}{\multicolumn{4}{|c|}{$\begin{array}{l}\text { Number (and percentage) of adolescents reporting they regret having already had sexual relationships. } \\
\text { Odds ratios adjusted for all the variables in the table, and also for age, economic status and type of school } \\
\text { (public/private). }\end{array}$}} \\
\hline & & & \\
\hline \multicolumn{4}{|c|}{$\begin{array}{l}\text { Subjects were considered as "high religiosity" if they had a religion, reported attending temple at least once in a } \\
\text { week and agreed or highly agreed with the sentence "My faith is a very important influence that I am willing to } \\
\text { take into account in my life". }\end{array}$} \\
\hline
\end{tabular}




\section{REFERENCES}

1. World Health Organization. Global strategy for the prevention and control of sexually transmitted infections : 2006 - 2015 : breaking the chain of transmission. Geneva, World Health Organization, 2007.

2. Centers for Disease Control and Prevention. Youth Risk Behavior Surveillance-United States, 2007. Morbidity and Mortality Weekly Report, Surveillance Summaries. 2008;57(SS04):1-131.

3. Fenton KA, Breban R, Vardavas R, et al. Infectious syphilis in high-income settings in the 21st century. Lancet Infect Dis. 2008;8(4):244-253.

4. Louie KS, de Sanjose S, Diaz M, et al. Early age at first sexual intercourse and early pregnancy are risk factors for cervical cancer in developing countries. Br J Cancer. 2009;100(7):1191-1197.

5. Hallfors DD, Waller MW, Ford CA, Halpern CT, Brodish PH, Iritani B. Adolescent depression and suicide risk - Association with sex and drug behavior. Am J Prev Med. 2004;27(3):224-231.

6. Kaltiala-Heino R, Kosunen E, Rimpela M. Pubertal timing, sexual behaviour and selfreported depression in middle adolescence. Journal of adolescence. 2003;26(5):531-545.

7. Heidmets L, Samm A, Sisask M, Kolves K, Aasvee K, Varnik A. Sexual Behavior, Depressive Feelings, and Suicidality Among Estonian School Children Aged 13 to 15 Years. Crisis. 2010;31(3):128-136.

8. Albert B. With One Voice: America's Adults and Teens Sound Off About Teen Pregnancy. Washington, DC, National Campaign to Prevent Teen Pregnancy, 2007. 
9. Eshbaugh EM, Gute G. Hookups and Sexual Regret Among College Women. J Soc Psychol. 2008;148(1):77-89.

10. Wight D, Parkes A, Strange V, Allen E, Bonell C, Henderson M. The Quality of Young People's Heterosexual Relationships: A Longitudinal Analysis of Characteristics Shaping Subjective Experience. Perspect Sex Reprod Health. 2008;40(4):226-237.

11. Martino SC, Collins RL, Elliott MN, Kanouse DE, Berry SH. It's Better on TV: Does Television Set Teenagers Up for Regret Following Sexual Initiation? Perspect Sex Reprod Health. 2009;41(2):92-100.

12. Dickson N, Paul C, Herbison P, Silva P. First sexual intercourse: age, coercion, and later regrets reported by a birth cohort. BMJ. 1998;316(7124):29-33.

13. Wellings F, Nanchahal K, Macdowall W, et al. Sexual behaviour in Britain: early heterosexual experience. Lancet. 2001;358(9296):1843-1850.

14. Houts LA. But was it wanted? Young women's first voluntary sexual intercourse. J Fam Issues. 2005;26(8):1082-1102.

15. Beres MA. 'Spontaneous' sexual consent: An analysis of sexual consent literature. Feminism \& Psychology. 2007;17(1):93-108.

16. Impett EA, Peplau LA. Why some women consent to unwanted sex with a dating partner: Insights from attachment theory. Psychol Women Q. 2002;26(4):360-370.

17. Babalola S. Perceived peer behavior and the timing of sexual debut in Rwanda: A survival analysis of youth data. Journal of youth and adolescence. 2004;33(4):353. 
18. Layte R, McGee H. Regret about the Timing of First Sexual Intercourse: The Role of Age and Context (ESRI Working Paper No 217). Dublin, Economic and Social Research Institute, 2007.

19. Oswalt SB, Cameron KA, Koob JJ. Sexual regret in college students. Arch Sex Behav. 2005;34(6):663-669.

20. World Economic Forum. Women’s Empowerment: Measuring the Global Gender Gap. Geneva, Switzerland, World Economic Forum, 2005.

21. de Irala J, Osorio A, López-del Burgo C, et al. Relationships, love and sexuality: what the Filipino teens think and feel. BMC Public Health. 2009;9(282):282.

22. Hosmer D LS. Applied Logistic Regression. $2^{\circ}$ ed. N York, Willey, 2000.

23. Vittinghoff E, McCulloch CE. Relaxing the rule of ten events per variable in logistic and Cox regression. Am J Epidemiol. 2007;165(6):710-718.

24. Tourangeau R, Yan T. Sensitive questions in surveys. Psychol Bull. 2007;133(5):859-883. 25. de Irala J, Osorio A, Carlos S, Ruiz-Canela M, Lopez-Del Burgo C. Mean Age of First Sex: Do They Know What We Mean? Arch Sex Behav. 2011;40:853-855.

26. U.S. Department of Health \& Human Services. Many Teens Are Saying "No". Teen Talk. 2005;1. Available at: http://www.hhs.gov/opa/pdfs/teen-talk-vol-1.pdf. Accessed August 10, 2011.

27. Ott MA, Pfeiffer EJ, Fortenberry JD. Perceptions of sexual abstinence among high-risk early and middle adolescents. J Adolesc Health. 2006;39(2):192-198. 
28. Masters NT, Beadnell BA, Morrison DM, Hoppe MJ, Gillmore MR. The opposite of sex? Adolescents' thoughts about abstinence and sex, and their sexual behavior. Perspect Sex Reprod Health. 2008;40(2):87-93.

29. Darling CA, Davidson JK, Passarello LC. The Mystique of 1st Intercourse among College Youth - the Role of Partners, Contraceptive Practices, and Psychological Reactions. Journal of Youth and Adolescence. 1992;21(1):97-117.

30. Bernik I, Hlebec V. How did it happen the first time? Sexual initiation of secondary school students in seven postsocialist countries. In: Štulhofer A, Sandfort T, eds. Sexuality and gender in postcommunist Eastern Europe and Russia. New York: The Haworth Press; 2005:297-315.

31. Guggino JM, Ponzetti JJ. Gender differences in affective reactions to first coitus. Journal of adolescence. 1997;20(2):189-200.

32. Aras S, Semin S, Gunay T, Orcin E, Ozan S. Sexual attitudes and risk-taking behaviors of high school students in Turkey. J Sch Health. 2007;77(7):359-366.

33. Mercer CH, Wellings K, Macdowall W, et al. First sexual partnerships - Age differences and their significance: Empirical evidence from the 2000 British National Survey of Sexual Attitudes and Lifestyles ('Natsal 2000'). J Adolesc Health. 2006;39(1):87-95.

34. Wight D, Henderson M, Raab G, et al. Extent of regretted sexual intercourse among young teenagers in Scotland: a cross sectional survey. BMJ. 2000;320(7244):1243-1244.

35. Cotton S, Mills L, Succop PA, Biro FM, Rosenthal SL. Adolescent girls' perceptions of the timing of their sexual initiation: "Too young" or "Just right". J Adolesc Health. 2004;34(5):453-458. 
36. Carpenter LM. The first time/das erstes mal - Approaches to virginity loss in US and German teen magazines. Youth \& Society. 2001;33(1):31-61.

37. Rivadeneyra R, Lebo MJ. The association between television-viewing behaviors and adolescent dating role attitudes and behaviors. Journal of adolescence. 2008;31(3):291-305.

38. Taverner B, Montfort S. Making Sense of Abstinence. Lessons for Comprehensive Sex Education. Morristown, NJ, Planned Parenthood of Greater Northern New Jersey, 2005. 39. Jemmott LS, Jemmott JB, McCaffree KA. Be Proud! Be Responsible! Strategies to empower youth to reduce their risk for HIV infection. New York, Select Media, 2006. 40. Berkowitz AD. An overview of the social norms approach. In: Lederman LC, Stewart LP, eds. Changing The Culture Of College Drinking: A Socially Situated Health Communication Campaign. Cresskill, NJ: Hampton Press; 2005:193-214. 